\title{
Normal serum prostate specific antigen levels in men in Yasuj province, Islamic Republic of Iran
}

S. Mehrabi, ${ }^{1}$ H.R. Ghafarian Shirhzi ${ }^{1}$ and M. Rasti ${ }^{1}$

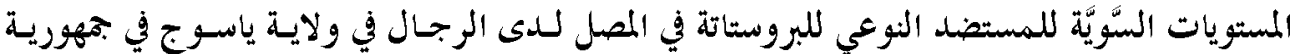

$$
\begin{aligned}
& \text { إيران الإسلامية }
\end{aligned}
$$

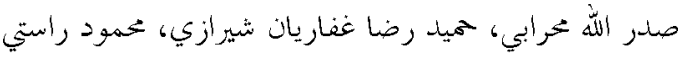

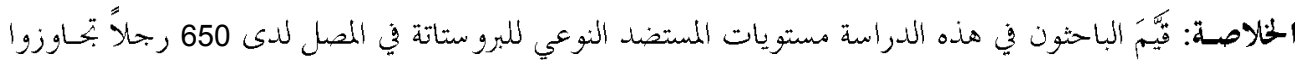

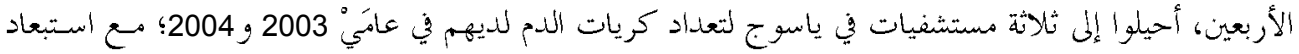

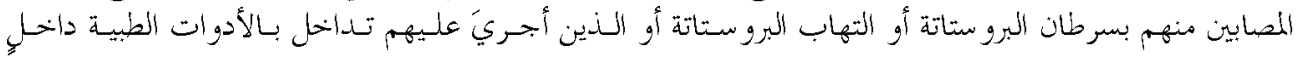

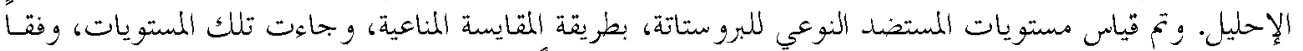

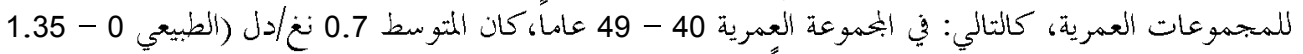

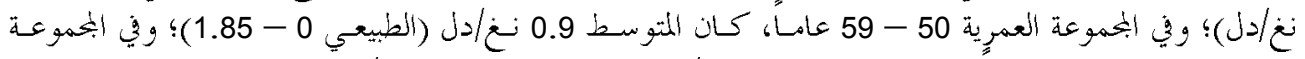

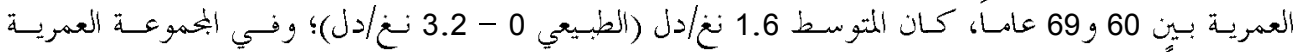

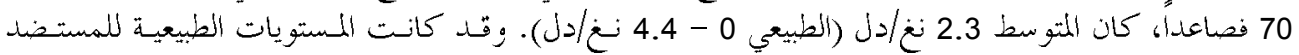

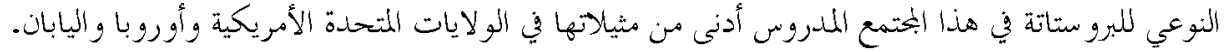

ABSTRACT We assessed serum prostate specific antigen (PSA) levels in 650 men over 40 years referred to 3 Yasuj hospitals for blood cell count in 2003/2004. Men affected by prostate cancer, prostatitis or transurethral instrumentation were excluded. PSA was determined by an immunoassay technique. PSA levels in different age groups were: $40-49$-year-olds-mean $=0.7 \mathrm{ng} / \mathrm{dL}$, normal $=0-1.35 \mathrm{ng} / \mathrm{dL}$; 50-59-year-olds-mean $=0.9 \mathrm{ng} / \mathrm{dL}$, normal $=0-1.85 \mathrm{ng} / \mathrm{dL} ; 60-69$-year-olds-mean $=1.6 \mathrm{ng} / \mathrm{dL}$, normal $=0-3.2 \mathrm{ng} / \mathrm{dL} ; \geq 70$-years-olds-mean $=2.3 \mathrm{ng} / \mathrm{dL}$, normal $=0-4.4 \mathrm{ng} / \mathrm{dL}$. Normal PSA levels in our society were lower than those in the United States, Europe and Japan.

Taux sérique normal d'antigène spécifique de la prostate chez les hommes de la province de Yasuj en République islamique d'Iran

RÉSUMÉ Nous avons évalué le taux d'antigène spécifique de la prostate (ou PSA, pour prostate specific antigen ) chez 650 hommes âgés de plus de 40 ans et dirigés en 2003/2004 sur 3 hôpitaux de Yasuj pour numération globulaire (NFS). Ont été exclus de l'étude les hommes porteurs d'un cancer de la prostate ou d'une prostatite ou ayant subi une instrumentation urétrale. Le PSA a été déterminé par immunodosage. Le taux de PSA dans les différentes tranches d'âge était le suivant : 40-49 ans moyenne $=0,7 \mathrm{ng} / \mathrm{dL}$, normale $=0-1,35 \mathrm{ng} / \mathrm{dL} ; 50-59$ ans moyenne $=0,9 \mathrm{ng} / \mathrm{dL}$, normale $=0-1,85 \mathrm{ng} / \mathrm{dlL}$; 60-69 ans moyenne $=1,6 \mathrm{ng} / \mathrm{dL}$, normale $=0-3,2 \mathrm{ng} / \mathrm{dL} ; \geq 70$ ans moyenne $=2,3 \mathrm{ng} / \mathrm{dL}$, normale $=$ 0-4,4 ng/dL. Les taux normaux de PSA observés dans notre population s'avèrent inférieurs à ceux enregistrés aux États-Unis, en Europe et au Japon.

'School of Medicine, Yasuj University of Medical Sciences, Yasuj, Islamic Republic of Iran (Correspondence to S. Mehrabi:mehrabi390@yahoo.com).

Received: 06/02/05; accepted: 03/05/05 


\section{Introduction}

More than 1 million new cases of cancer are diagnosed annually in America: prostate cancer, with a prevalence of $19 \%$, comes second after lung cancer as the most prevalent neoplasm in men. The prevalence of prostate cancer increases with age: there is 1 case in 103 in men aged $40-59$ years old and 1 case in 8 in men over 80 years [1]. High prevalence, simple diagnosis and definite treatment make the early diagnosis of such cancers important.

The best screening method for prostate cancer is combined digital rectal exam and determination of serum prostate specific antigen (PSA) level. Although PSA is not specific for prostate cancer and other factors such as benign prostatic hyperplasia, introduction of diagnostic and therapeutic instruments and prostatitis can increase its concentration, PSA is still the best screening test for patients suspected of prostate cancer $[1,2]$.

It is known that PSA blood level is dependent on age, race and geographical region of residence [3] and recently there have studies regarding the value of PSA for detecting prostate cancer $[2,4]$. As there have been no studies of normal PSA levels in the Islamic Republic of Iran, we aimed to determine the normal level of PSA in Iranian men in the south-west of the country and compare this with levels reported in other countries and geographical regions.

\section{Methods}

This was a cross-sectional study of a sample of men over 40 years who had been referred to 3 Yasuj hospitals for blood cell count for reasons other than prostate cancer between March 2003 and April 2004. These included men with prostatitis, urinary tract infections, history of urethral instrumenta- tion, transurethral resection of the prostate, prostatectomy and those having digital rectal exam (many of them referred for annual check-up). The sample was classified according to weight in age groups. The sample size was calculated with $\alpha$ level of 0.05 and $\beta=0.2$ assuming that $25 \%$ of the population in Yasuj were over 40 years. Men affected by prostate cancer, bacterial prostatitis or transurethral resection were excluded from the study. Thus a sample of 650 men was recruited: 210 aged 40-49 years, 180 aged $50-59$ years, 150 aged $60-69$ years and 110 aged 70 years and over.

Blood samples were taken and $1 \mathrm{~mL}$ of centrifuged serum was used for the PSA test. Serum was analysed by immunoassay using a monoclonal antibody kit (Kavoshyar Iran, Islamic Republic of Iran). Fine instruments were used to measure PSA level with $0.05 \mathrm{ng}$ precision. Normal range of PSA was considered between 0 and 95 th percentile.

The data were analysed by SPSS, version 12 .

\section{Results}

The mean level of PSA in the 40-49-yearold age group was $0.7 \mathrm{ng} / \mathrm{dL}$. The normal range (0-95th percentile) was $0-1.35 \mathrm{ng} / \mathrm{dL}$ and 198 men fell within this range. There were 8 men in whom the PSA level was between the 95th and 99th percentiles (1.35$1.50 \mathrm{ng} / \mathrm{dL}$ ) and were considered borderline group for prostate cancer. The remainder (4) fell outside these (99th-100th centile).

The mean level of PSA in the 50-59year-old age group was $0.9 \mathrm{ng} / \mathrm{dL}$. The normal range (0-95th percentile) was $0-1.85$ $\mathrm{ng} / \mathrm{dL}$ and 167 men fell within this range. There were 10 men within the 95th-99th percentile (1.85-2.25 ng/dL) (borderline). The remainder (3) fell outside these (99th100th centile). 
The mean level of PSA in the 60-69year-old age group was $1.6 \mathrm{ng} / \mathrm{dL}$. The normal range (0-95th percentile) was $0-3.2$ $\mathrm{ng} / \mathrm{dL}$ and 140 men fell within this range. There were 8 men within the 95th-99th percentile (3.2-3.7 ng/dL) (borderline). The remainder (2) fell outside these (99th-100th centile).

The mean PSA level in the 70 years and older age group was $2.2 \mathrm{ng} / \mathrm{dL}$. The normal range (0-95th percentile) was $0-4.4 \mathrm{ng} / \mathrm{dL}$ and 102 men fell within this range. There were 6 men within the 95th-99th percentile (4.4-4.6 ng/dL) (borderline). The remainder (2) fell outside these (99th-100th centile).

Our results in comparison with other studies are shown in Tables 1 and 2.

\section{Discussion}

Comparison of our study with other studies (Tables 1 and 2) indicates that the normal PSA level in our study group is lower than of the United States of America (USA), Europe and Japan [5-8]. In fact, in all age groups over 40 years the normal and borderline values of PSA in Iranian men were lower than in American, European and Japanese men. However, they were closer to the values for Japanese men. In a study of 2119 residents of Minnesota, USA in 1994, Oesterling and colleagues reported that the normal level of PSA for all age groups was between 0.00 and $5.50 \mathrm{ng} / \mathrm{dL}$ and a PSA level of $2.40-6.50 \mathrm{ng} / \mathrm{dL}$ was considered borderline [5]. An important result of this study was that normal PSA levels in different races were different, such that African-American men had higher and Asian-American men had lower normal PSA level than white American men [5]. De Antoni and colleagues found significant differences in mean PSA by race [6]. They found pairwise differences in mean PSA between whites and blacks, whites and Latinos, blacks and Asians, and Asians and Latinos $(P<0.0001)$. No statistically significant differences in PSA variance between racial groups were found. Age-within-race analysis resulted in consistent statistical significance when comparing variance among age cohorts in each race.

Oesterling et al. conducted a study of 650 men in Kyoto in Japan with the aim of finding the normal PSA level in Japanese men. The men studied had no history of enlarged prostate, treated prostate cancer or active prostate infection and were not under treatment for diseases related to the prostate. The results showed that normal PSA levels were lower than Americans, again indicting that race affects the PSA level [8]. Although our study was conducted on 1 hospital sample from a small province of the Islamic Republic of Iran and therefore the results cannot be generalized to the whole country,

Table 1 Normal serum prostate specific antigen range (0-95th
percentile) in different regions [5-8]
\begin{tabular}{lccccc}
\hline $\begin{array}{l}\text { Age group } \\
\text { (years) }\end{array}$ & $\begin{array}{c}\text { Prostate specific antigen: } \\
\text { Yasuj }\end{array}$ & USA & E5th percentile (ng/dL) \\
\hline $40-49$ & $0.00-1.35$ & $0.00-2.40$ & $0.00-2.00$ & $0.00-1.50$ \\
$50-59$ & $0.00-1.85$ & $0.00-3.90$ & $0.00-3.80$ & $0.00-2.00$ \\
$60-69$ & $0.00-3.20$ & $0.00-4.50$ & $0.00-4.20$ & $0.00-3.40$ \\
$\geq 70$ & $0.00-4.40$ & $0.00-5.50$ & $0.00-5.50$ & $0.00-4.50$ \\
\hline
\end{tabular}




\begin{tabular}{|c|c|c|c|c|}
\hline \multirow{2}{*}{$\begin{array}{l}\text { Age group } \\
\text { (years) }\end{array}$} & \multicolumn{4}{|c|}{ Prostate specific antigen: 95th-99th percentile (ng/dL) } \\
\hline & Yasuj & America & Europe & Japan \\
\hline $40-49$ & $1.35-1.50$ & $2.40-2.60$ & $2.00-2.40$ & $1.50-1.70$ \\
\hline $50-59$ & $1.85-2.25$ & $3.90-4.50$ & $3.80-4.10$ & $2.00-2.40$ \\
\hline $60-69$ & $3.20-3.70$ & $4.50-5.10$ & $4.20-5.00$ & $3.40-3.90$ \\
\hline$\geq 70$ & $4.40-4.60$ & $5.50-6.50$ & $5.50-6.50$ & $4.50-4.80$ \\
\hline
\end{tabular}

the PSA level in our study are very similar to Japanese men (an Asian race).

PSA was investigated in a study in 1998 of English men in London without treated or active prostate cancer or infection [9]. In addition they had not had rectal examination in the past 48 hours. The results showed that normal PSA levels in this population were similar to those in the USA. In addition, when the prostates of the men with PSA higher than normal levels were biopsied by transrectal sonography, $85 \%$ of the men had at least 1 early focus of malignancy [9].

As researchers in the USA have shown, Asians have lower PSA levels than other races (African and Americans) [10,11]. It is not known why the PSA level in Asians is lower than Americans. It may be that androgen levels in Asians are lower but there have not been any studies investigating this $[10,11]$.

Since small foci of dysplasia and cellular malignancy in prostate mass could increase PSA concentration above the normal level of the population, Americans could have backgrounds for prostate cancer (greater than Asians) that have increased PSA levels in Americans [12].

Benign hyperplasia of the prostate is another reason for slightly increased PSA levels. After surgery some part of the prostate tumour will be lost and as a result the PSA level decreases. One reason for the low level of PSA in our sample could be a higher number of surgeries for treatment of benign hypertrophy of the prostate. This is because effective drugs for medical treatment of benign hypertrophy of the prostate, such as tamsulosin, were not easily available in our country during the study and therefore surgery was preferred by our patients. There is even a possibility that nutrition or geographical region or distance from the equator affect PSA level but there have been no comprehensive studies of such hypotheses [13].

Stamey et al. reviewed the PSA levels of 1317 patients with prostate cancer and reported that in the last 5 years, serum PSA has only been related to benign prostatic hyperplasia and there is an urgent need for another more specific marker for screening of prostate cancer. However, their samples were from patients with cancer not from the general population, and also no new serum marker has yet been identified. Therefore measuring PSA level is still one of the best screening methods for detecting prostate cancer and follows-up [2,14].

One of the limitations of our study is that, because of expenses, sonography was not used for exclusion of possible of prostate cancer and also there was no follow-up of cases in whom the PSA level was higher than borderline. It is suggested that a similar study at the national level be done with sampling and sonography in cases where PSA is higher than borderline. 


\section{References}

1. Ballentine H, Partin AW. Diagnosis and staging of prostate cancer. In: Walsh $\mathrm{PC}$ et al., eds. Campbell urology, 8th ed. Philadelphia, WB Saunders Company, 2002:3055-79.

2. Stamey TA et al. The prostate specific antigen era in the United States is over for prostate cancer: What happened in the last 20 years? Journal of urology, 2004, 172:1297-301.

3. Antonopoulos IM et al. Racial differences in prostate cancer prevalence. International braz $j$ urol: official journal of the Brazilian Society of Urology, 2002, 28:214-20.

4. Moul JW et al. Prostate-specific antigen values at the time of prostate cancer diagnosis in African-American men. Journal of the American Medical Association, 1995, 25:1277-81.

5. Oesterling JE et al. Serum prostatespecific antigen in a community-based population of healthy men. Establishment of age-specific reference ranges. Journal of the American Medical Association, 1993, 270(7):860-4.

6. DeAntoni EP et al. Age- and racespecific reference ranges for prostatespecific antigen from a large communitybased study. Urology, 1996, 48(2):2349.

7. Aragona $\mathrm{F}$ et al. Incidence of prostate cancer in Sicily: results of a multicenter case-findings protocol. European urology, 2005, 47(5):569-74.

8. Oesterling JE et al. Serum prostate-specific antigen in a community-based popu- lation of healthy Japanese men: lower values than for similarly aged white men. British journal of urology, 1995, 75:34753.

9. Weinrich $\mathrm{MC}$ et al. Reference ranges for serum prostate-specific antigen in black and white men without cancer. Urology, 1998, 52(6):967-73.

10. Henderson RJ et al. Prostate-specific antigen (PSA) and PSA density: racial differences in men without prostate cancer. National Cancer Institute, 1997, 89(2):134-8.

11. Abdalla I et al. Comparison of serum prostate-specific antigen levels and PSA density in African-American, white, and Hispanic men without prostate cancer. Urology, 1998, 51(2):300-5.

12. Eastham JA et al. Clinical characteristics and biopsy specimen features in AfricanAmerican and white men without prostate cancer. Journal of the National Cancer Institute, 1998, 90(10):756-60.

13. Eastham JA et al. Racial variation in prostate specific antigen in a large cohort of men without prostate cancer. Journal of the Louisiana State Medical Society: official organ of the Louisiana State, 2001, 153(4):184-9.

14. Fowler JE Jr et al. Prospective study of correlations between biopsy-detected high grade prostatic intraepithelial neoplasia, serum prostate specific antigen concentration and race. Cancer, 2001, 91(7):1291-6. 